Sains Malaysiana 49(12)(2020): 3145-3154

http://dx.doi.org/10.17576/jsm-2020-4912-26

\title{
Electrochemical Reaction and Dissociation of Glycerol on PdAu Surface Catalyst
}

(Tindak Balas Elektrokimia dan Pemisahan Gliserol pada Permukaan Pemangkin PdAu)

\author{
Nabila A. Karim*, Norilhamiah Yahya, Muhammad SyafiQ \& Siti Kartom Kamarudin
}

\section{ABSTRACT}

Direct Glycerol Fuel Cell is one of the alternative energy that can produce electricity without burning. The production of electricity without combustion can reduce the use of fossil fuel as well as reduce environmental pollution. A new catalyst of PdAu has been synthesized in this study to increase the activity of the glycerol oxidation reaction. Morphologies analysis was performed on CNF-supported synthesized PdAu. FESEM and TEM image show the PdAu supported on the CNF surface. Both PdAu and CNF has a diameter size of 4-6 nm and 80-130 nm, respectively. In $\mathrm{CV}$ analysis, PdAu/CNF has produced an oxidation peak and current density at $-0.9 \mathrm{~V} v \mathrm{~s}$. SCE and $70 \mathrm{~mA} / \mathrm{cm}^{2}$, respectively. Each mechanism of glycerol dissociation step during glycerol oxidation, different atomic active sites are required in PdAu. For example, for glycerol adsorption, Au atom as an active site while for ${ }^{*} \mathrm{C}_{3} \mathrm{H}_{7} \mathrm{O}_{3}$ requires $\mathrm{Pd}$ atom and Au atom as the active site. The Au catalyst model shows better adsorption as Au/CNF has a slightly more negative oxidation peak than PdAu. Nevertheless, the Au catalyst showed less durability compared to PdAu.

Keywords: Electro-catalyst; electrochemical reaction; glycerol; PdAu; surface reaction

\section{ABSTRAK}

Sel Bahan Api Gliserol Langsung adalah salah satu tenaga alternatif yang dapat menghasilkan elektrik tanpa proses pembakaran. Pengeluaran elektrik tanpa pembakaran dapat mengurangkan penggunaan bahan bakar fosil serta mengurangkan pencemaran alam sekitar. Mangkin baru PdAu telah disintesis dalam kajian ini untuk meningkatkan aktiviti tindak balas pengoksidaan gliserol. Analisis morfologi dilakukan pada PdAu yang telah disintesis dan disokong oleh CNF. Gambar FESEM dan TEM menunjukkan PdAu disokong pada permukaan CNF. Kedua-dua PdAu dan CNF masing-masing mempunyai ukuran diameter 4-6 nm dan 80-130 nm. Dalam analisis CV, PdAu/CNF telah menghasilkan puncak pengoksidaan dan ketumpatan arus masing-masing pada $-0.9 \mathrm{~V}$ vs SCE dan $70 \mathrm{~mA} / \mathrm{cm}^{2}$. Setiap mekanisme langkah pemisahan gliserol semasa pengoksidaan gliserol, tapak aktif atom yang berbeza diperlukan dalam PdAu. Sebagai contoh, untuk penjerapan gliserol, atom Au sebagai tapak aktif sementara untuk $* \mathrm{C}_{3} \mathrm{H}_{7} \mathrm{O}_{3}$ memerlukan atom Pd dan atom Au sebagai tapak aktif. Model mangkin Au menunjukkan penjerapan yang lebih baik kerana Au/CNF mempunyai puncak pengoksidaan yang sedikit lebih negatif daripada PdAu. Walaupun begitu, mangkin Au menunjukkan daya tahan yang lebih rendah berbanding dengan PdAu.

Kata kunci: Elektro-mangkin; gliserol; permukaan tindak balas; PdAu tindak balas elektrokimia

\section{INTRODUCTION}

The use of fossil fuel in energy production has caused fossil fuel resources to decrease and also cause environmental pollution (Alias et al. 2020; Day \& Day 2017; Wang et al. 2018). Therefore, alternative energy is needed to replace the use of fossil fuel. Various alternative energy is being developed, and fuel cells have shown one of the technologies to be proud of to replace fossil fuel (Wang et al. 2018). Fuel cells have different types depending on fuel consumption (Karim \& Kamarudin 2017). Polymer electrolyte membrane fuel cell uses hydrogen as fuel. The use of hydrogen as fuel despite producing high energy, but problems such as storage and transportation have led to the use of Direct Liquid Fuel Cell (DLFC) (Abdullah et al. 2017; Mori \& Hirose 2009).

Glycerol is one of the forms in DLFC and is called Direct Glycerol Fuel Cell (DGFC). The use of glycerol as fuel has advantages such as low pollution, high energy density, rapid start-up, simplicity, and few safety concerns (Karim et al. 2017). Glycerol has a more complex structure compared to methanol leading to the production of various intermediate reactions (Yahya et al. 2017). The complex structure also leads to a sluggish reaction in the DGFC (Nascimento \& Linares 2014; Zakaria et al. 2019). 
Commonly used catalysts in the glycerol oxidation reaction are Pt and Pt-based catalysts (Wang et al. 2017). Tam et al. (2019) synthesized the PtRu to enhance the electrochemical reaction of glycerol compared to bare $\mathrm{Pt}$. The authors found that there are about $40 \%$ of $\mathrm{Pt}$ (100) sites and only a small amount of Pt (111) sites. A different facet of the Pt gives different catalytic activity and mechanism reactions of glycerol. The addition of $\mathrm{Ru}$ metal in Pt to form PtRu alloy showed an increase in the onset potential for the oxidation of carbon monoxide (CO). The $\mathrm{CO}$ is the last intermediate product before a complete glycerol oxidation reaction. A study by Brueckner et al. (2019) used Sn oxide as support for the PtRu and PtRh catalyst. The PtRu catalyst showed remarkable catalytic activity of the glycerol oxidation compared to the PtRh. The authors also stated that these catalysts are not as highly active as compared using other fuels such as methanol and ethanol.

Martins et al. (2019) investigated the in-situ preparation of $\mathrm{PtFe} / \mathrm{C}$ to prevent the costly and timeconsuming preparation of catalysts for the oxidation reaction of glycerol (Martins et al. 2019). The in-situ technique can control and increase the Fe ad-atom on the Pt metal. The ultra-low loading of $\mathrm{Fe}$ in $\mathrm{PtFe}$ has increased the power density by $36 \%$, reaching $54 \mathrm{~mW} /$ $\mathrm{cm}^{2}$. Zhou et al. (2019) synthesized the PtAg skeleton showed 15.4 times higher in activity compared to the $\mathrm{Pt} / \mathrm{C}$. The authors also conducted the product analysis using liquid chromatography and found that the product of dihydroxyacetone showed $82.6 \%$ selectivity in the glycerol oxidation reaction. Other product compounds found in the same analysis are tartronic acid, glyceric acid, glyceraldehyde, glycolic acid, oxalate acid, and glyoxylic acid.

Gao et al. (2019) synthesized the 1D structure of PtNi for the high catalytic activity of the glycerol oxidation reaction. Different structures of PtNi have been developed in this study, and there are ultrafine nanowires, sinuous nanowires, and ultrashort nanowires. The structures obtained by controlling the amount of citric acid, ascorbic acid, and glucose. The electrochemical reaction and mass activity increase about 4.3 and 3.9 times higher than the commercial catalyst of $\mathrm{Pt} / \mathrm{C}$, respectively. Zhang et al. (2019) also conducted the PtNi nanorod and found the optimized atomic ratio $\mathrm{Pt}$ to $\mathrm{Ni}$ is the best at 3:1 for the glycerol oxidation reaction. The value of the mass activity is $4601.5 \mathrm{~mA} / \mathrm{mg}$, which is 4.6 times higher than commercial $\mathrm{Pt} / \mathrm{C}$.

While Araujo et al. (2019) studied the effect of Sn adsorption on the Pt surface for the electrochemical oxidation reaction of glycerol, the authors found that there are sequences in the facet of adsorption of $\mathrm{Sn}$ on $\mathrm{Pt}$ that increase the activity of glycerol oxidation reaction. The sequence facet that has high activity is (100) terraces followed by the (100) short domains and then the (110) domains. However, the oxidation of CO is low on (100) terraces. Not only that, the addition of $\mathrm{Sn}$ on the Pt surface also increases the breaking bond of C-C in glycerol. Sun et al. (2019) studied the different atomic ratio of $\mathrm{Pt}$ and Co in PtCo nanowires for the electrochemical oxidation reaction of glycerol. The PtCo that has an atomic ratio 89:11 is the best ratio for glycerol oxidation reaction give mass and specific activities of $4573.0 \mathrm{~mA} / \mathrm{mg}$ and $11.9 \mathrm{~mA} / \mathrm{cm}^{2}$, respectively. In addition to the attractive catalyst structure and high catalytic surface area, the use of support also plays an important role in increasing the electrochemical reaction activity of the glycerol. Various catalyst support has been produced, such as graphene foam (Cui et al. 2019), carbon nanotubes (Ning et al. 2019), and graphitic carbon nanosheets (Ghosh et al. 2019). Cui et al. (2019) used the graphene foam as support for ultra-small Pd nanoparticles. The graphene foam is synthesized from lamellar MCM-22 zeolite as a template has given the catalytic activity as 1.7-2.9 times higher than the $\mathrm{Pd} / \mathrm{C}$ commercial catalyst. A carbon nanotube that has been doped with $\mathrm{S}$ to support the Pt nanoparticle catalyst was produced by Ning et al. (2019). The interaction of carbon and sulphur atoms in the S-doped carbon nanotubes has reduced the formation of poisonous intermediates and in thus, has increased catalyst stability.

The use of the Pt catalyst prone to be poisoned and costly (Karim et al. 2017). Therefore, the search for catalyst production other than $\mathrm{Pt}$ is very necessary. Pd catalyst has advantages and durability compared to Pt-based catalyst (Wang et al. 2017). Houache et al. (2019) developed the NiPd alloy for electro-oxidation of glycerol, and they found that formation of various by-products using polarization modulation infrared reflection absorption spectroscopy analysis. The primary by-products are mesoxalate, tartronate, and glyceraldehyde.

A study by Ghosh et al. (2019) that using PdFe as a catalyst in various atomic ratios of $\mathrm{Pd}$ to $\mathrm{Fe}$. The authors found that the mass activity of the glycerol is $1.86 \mathrm{~A} / \mathrm{mg}$ is higher using PdFe compared to the PdPt nanowires and other Pd-based catalysts. At the same time, Wang et al. (2019) investigated the effect of PdAg particle size towards the glycerol electro-oxidation reaction. The authors synthesized several particle sizes from 3.1 to 7.8 $\mathrm{nm}$. The PdAg that have a particle size of $3.1 \mathrm{~nm}$ showed remarkable and excellent activity with the mass activity of $3.51 \mathrm{~A} / \mathrm{mg}$ compared to other PdAg particle sizes. The addition of other metals to form alloy in pure Pd is beneficial because it can reduce agglomeration in pure Pd metal. Metal Au was selected in this study because of Au's resistance in a harsh environment. In addition, there is no study that investigate how the glycerol is dissociate at the catalyst surface during the glycerol oxidation reaction. Therefore, this study has been conducted 
in both experimental and theoretical studies for the electrochemical oxidation reaction and dissociation of glycerol using PdAu as a catalyst.

\section{MATERIALS AND METHODS}

All the reagent was bought from the Sigma-Aldrich. The $0.05 \mathrm{M} \mathrm{PdCl}_{2}$ (in $0.1 \mathrm{M} \mathrm{HCl}$ ) was mixed with $0.05 \mathrm{M}$ of $\mathrm{AuCl}_{3} \cdot \mathrm{HCl} \cdot 4 \mathrm{H}_{2} \mathrm{O}$ bring a total solution of $15 \mathrm{~mL}$. Some amount of trisodium citrate was dropped wisely. Then, this solution was added drop-wise to a stirred CNF slurry (isopropanol and deionized water) and went for $2 \mathrm{~h}$. After that, the reduction of the metal precursors is carried out using an appropriate amount of freshly prepared icecold sodium borohydride $\left(\mathrm{NaBH}_{4}\right)$, and the solution was stirred overnight at $10{ }^{\circ} \mathrm{C}$. Longer reaction time is needed to allow the sodium borohydride as it has strong reducing abilities to react with metal precursors to form the catalyst. The molar ratio $\mathrm{NaBH}_{4}$ : metal ions were taken at $5: 1$. The final product was filtered and washed with deionized water several times and dried at $80^{\circ} \mathrm{C}$ overnight. The synthesized catalysts are further morphological analysis using $\mathrm{x}$-ray diffraction (XRD), field emission scanning electron microscope (FESEM), and transmission electron microscopy (TEM).

The cyclic voltammetry measurement was performed by using Autolab electrochemical workstation at room temperature. The catalyst ink solution was carefully deposited onto the glassy carbon electrode surface by using a micropipette. The deposited catalyst was leave dried at room temperature. The electrochemical characterization of catalyst samples was studied in the potential range -0.7 to $0.4 \mathrm{~V}$ in $50 \mathrm{mV} / \mathrm{s}$ in $1 \mathrm{M} \mathrm{KOH}$ and at scan rate $50 \mathrm{mV} / \mathrm{s}$ in $0.5 \mathrm{M}$ glycerol/1 $\mathrm{M} \mathrm{KOH}$ solution. Both solutions were deoxygenated by bubbling with $\mathrm{N}_{2}$ at $200 \mathrm{~mL} / \mathrm{min}$ for $30 \mathrm{~min}$ before taking any measurement of the glycerol oxidation reaction.

The Materials Studio DMol3 (Version 5.5) is used in this study. Density functional theory (DFT) calculations were carried out with the PBE functional, while the effective potential with relativistic effect-accounted DFT semi-core DSPP was used for all calculations. DNPs, double numerical plus polarization function basis sets, was employed for all the calculations. The Monkhorst-Pack grid was set to $3 \times 3 \times 1$. The spin unrestricted method was used for all open-shell systems. The SCF criterion used was $1 \times 10^{-5}$ Hartree for the total energy. All structures were fully optimized without any symmetry constraints, with a convergence criterion of $0.004 \mathrm{Ha} \AA^{-1}$ for the forces, $0.005 \AA$ for the displacement, and $2 \times 10^{-5} \mathrm{Ha}$ for the energy change. Negative adsorption energy indicates that the adsorption is stable (exothermic) with respect to the free gas phase adsorbate.

\section{RESULTS AND DISCUSSION}

\section{MORPHOLOGY OF THE PDAU CATALYST SUPPORTED ON CNF}

Figure 1 shows the FESEM image of the PdAu catalyst supported on the CNF. As seen from the figure, the long rod refers to the $\mathrm{CNF}$ support materials. It looks very clear, showing that the small spherical particles are on the surface of the PdAu catalyst. These small spherical particles, refer to the nanoparticle of $\mathrm{PdAu}$, have been supported by CNF. Figure 2 shows the TEM image of

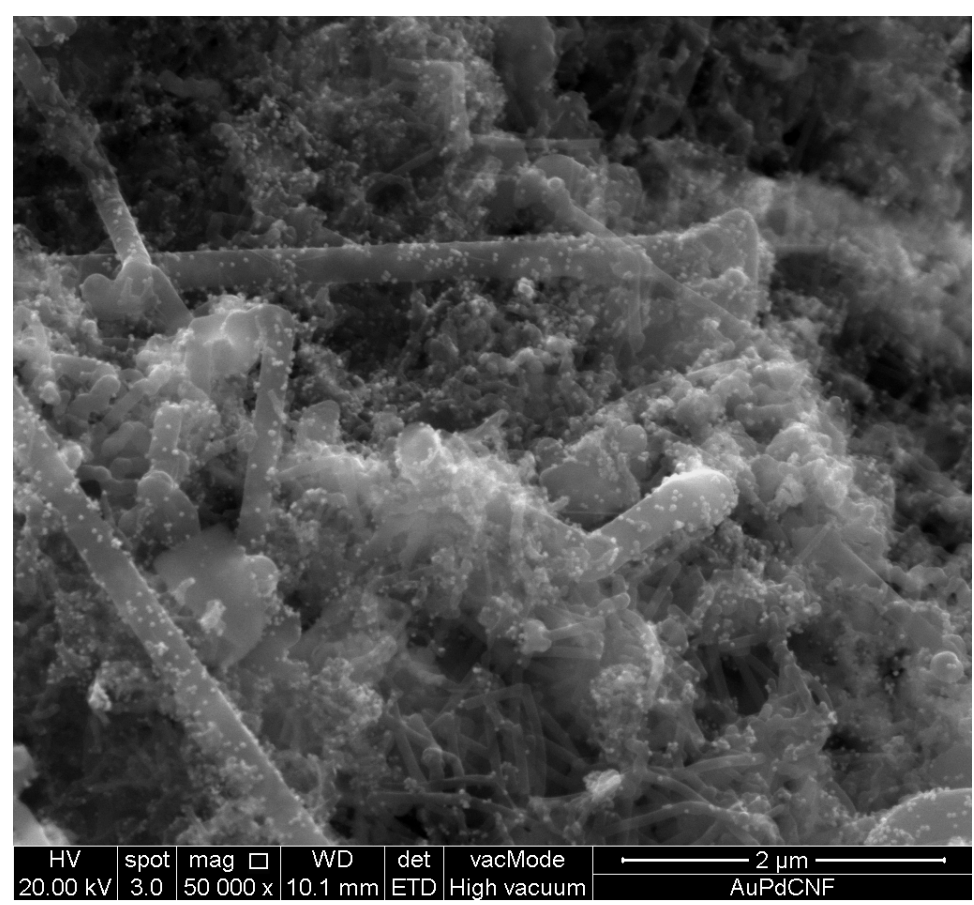

FIGURE 1. The FESEM image of the PdAu supported on CNF 
the PdAu supported on CNF. From Figure 2, the CNF has an average diameter size of 80 to $130 \mathrm{~nm}$. The small particles located on the CNF surface refer to PdAu nanoparticles having an average diameter size of $4 \mathrm{~nm}$ to $6 \mathrm{~nm}$. There is also a slight agglomeration of $\mathrm{PdAu}$ on the CNF surface. The synthesis of Pd alone is very difficult because Pd tends to agglomerate (Zhang et al. 1993). Pd alloyed with other metals can reduce agglomeration. Overall, PdAu synthesized and supported by CNF has successfully reduced the agglomeration of nanoparticles.
Figure 3 shows the XRD pattern for the $\mathrm{Au} / \mathrm{CNF}, \mathrm{Pd} /$ $\mathrm{CNF}$, and $\mathrm{PdAu} / \mathrm{CNF}$. The $\mathrm{Au} / \mathrm{CNF}$ and $\mathrm{Pd} / \mathrm{CNF}$ are also analyzed in the XRD pattern as references. From Figure $3, \mathrm{Au} / \mathrm{CNF}$ has diffraction peaks at $38.08,44.21,65.01$, and $77.80^{\circ}$ correspond to the (111), (200), (220), and (311), respectively. While the $\mathrm{Pd} / \mathrm{CNF}$ has the diffraction peaks at $39.84,46.53,67.53$, and $81.61^{\circ}$ refer to the (111), (200), (220), and (311), respectively. However, there is an apparent change in position of the diffraction peaks from the $\mathrm{Pd} / \mathrm{CNF}$ position towards the $\mathrm{Au} / \mathrm{CNF}$ position.

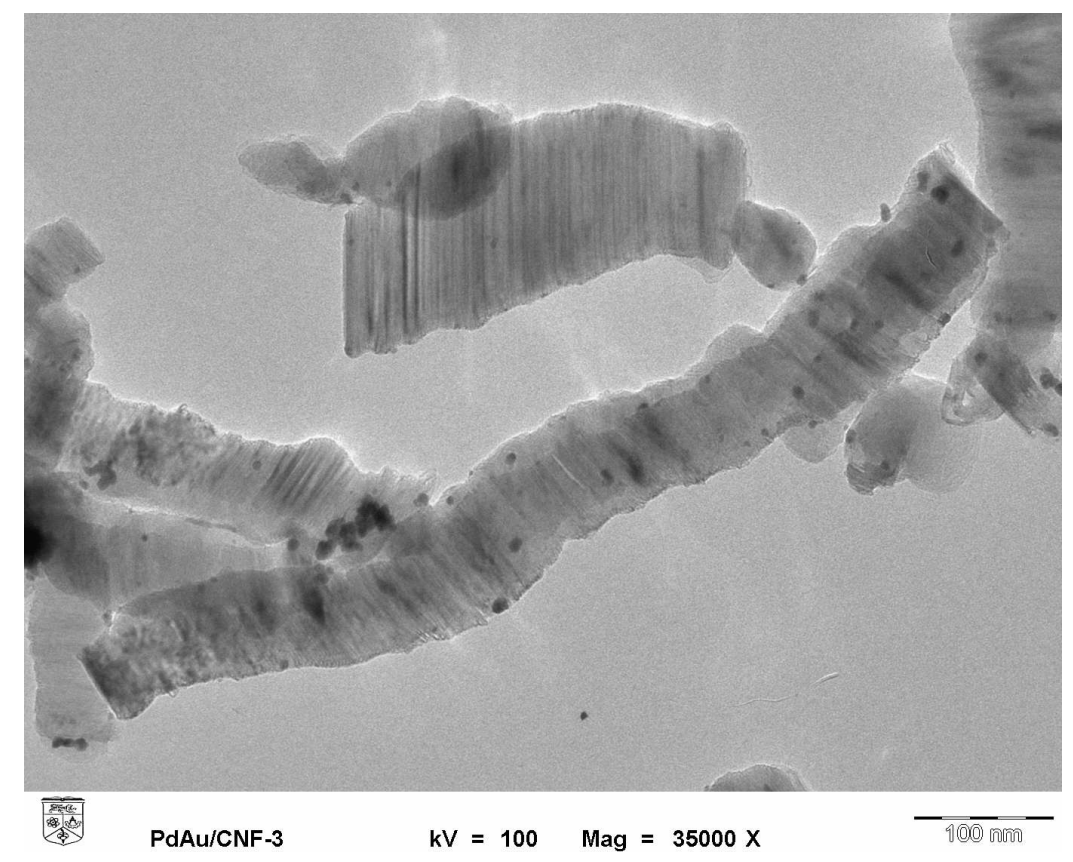

FIGURE 2. The TEM image of the PdAu supported on CNF

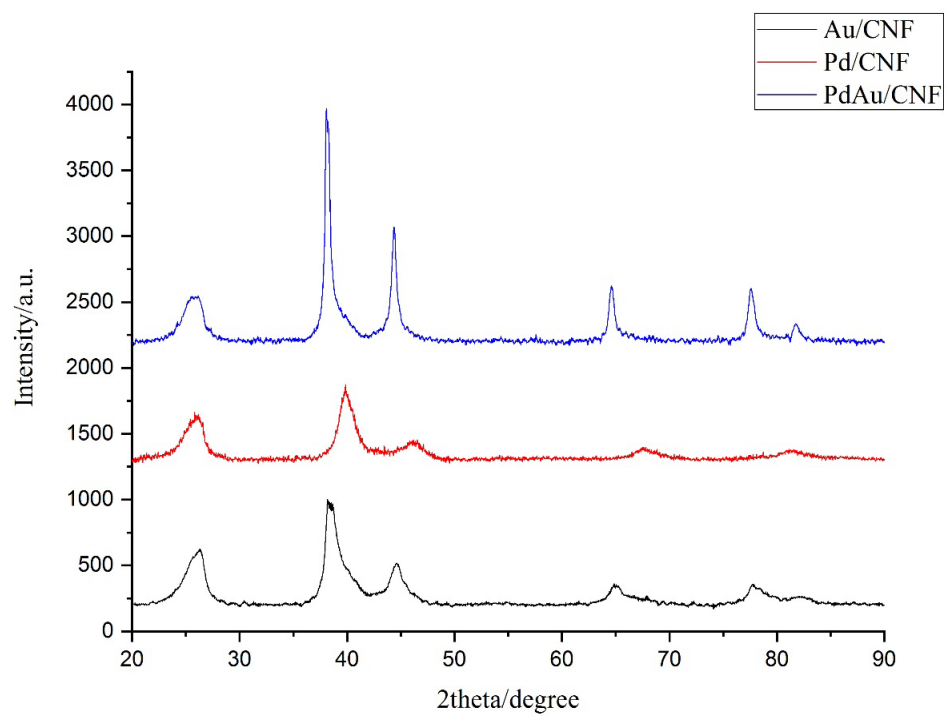

FIGURE 3. XRD pattern of the catalyst samples, $\mathrm{Au} / \mathrm{CNF}, \mathrm{Pd} / \mathrm{CNF}$, and $\mathrm{PdAu} / \mathrm{CNF}$ 


\section{ELECTROCHEMICAL REACTION OF THE PDAU IN GLYCEROL}

Figure 4 shows the cyclic voltammetry test in $50 \mathrm{mV} / \mathrm{s}$ in $1 \mathrm{M} \mathrm{KOH}$ for $\mathrm{Au} / \mathrm{CNF}, \mathrm{Pd} / \mathrm{CNF}$, and $\mathrm{PdAu} / \mathrm{CNF}$. There is no clear peak of $\mathrm{Au} / \mathrm{CNF}$ tested in this solution. However, the $\mathrm{Pd} / \mathrm{CNF}$ has a reduction peak occur at -0.38 $\mathrm{V}$ vs. SCE, and alloying the $\mathrm{Pd}$ with the $\mathrm{Au}$ in $\mathrm{PdAu} / \mathrm{CNF}$ showed a shifted peak at $-0.4 \mathrm{~V}$ vs. SCE. The catalysts are further tested in $50 \mathrm{mV} / \mathrm{s}$ in $0.5 \mathrm{M}$ glycerol $/ 1 \mathrm{M} \mathrm{KOH}$ solution, as shown in Figure 5. From Figure 5, the $\mathrm{Au} /$ CNF shows the lowest current density during the glycerol electrochemical reaction of $45 \mathrm{~mA} / \mathrm{cm}^{2}$. The oxidation peak of glycerol using $\mathrm{Au} / \mathrm{CNF}$ is at $-0.1 \mathrm{~V}$ vs. SCE. Compared to $\mathrm{Pd} / \mathrm{CNF}$ has a more negative oxidation peak at $-0.12 \mathrm{~V}$ vs. SCE. The current density at the oxidation peak in $\mathrm{Pd} /$ $\mathrm{CNF}$ is also higher than $\mathrm{Au} / \mathrm{CNF}$, which is $50 \mathrm{~mA} / \mathrm{cm}^{2}$. When inserting $\mathrm{Au}$ metal in $\mathrm{Pd}$ into $\mathrm{PdAu}$ and supported by CNF, the oxidation peak of the glycerol shifted a little positive at $-0.09 \mathrm{~V}$ vs. SCE. However, the current density at glycerol oxidation peak using $\mathrm{PdAu} / \mathrm{CNF}$ showed a very significant increase to $70 \mathrm{~mA} / \mathrm{cm}^{2}$. CNF-supported $\mathrm{PdAu}$ alloys have increased glycerol oxidation activity compared to $\mathrm{Pd} / \mathrm{CNF}$ and $\mathrm{Au} / \mathrm{CNF}$.

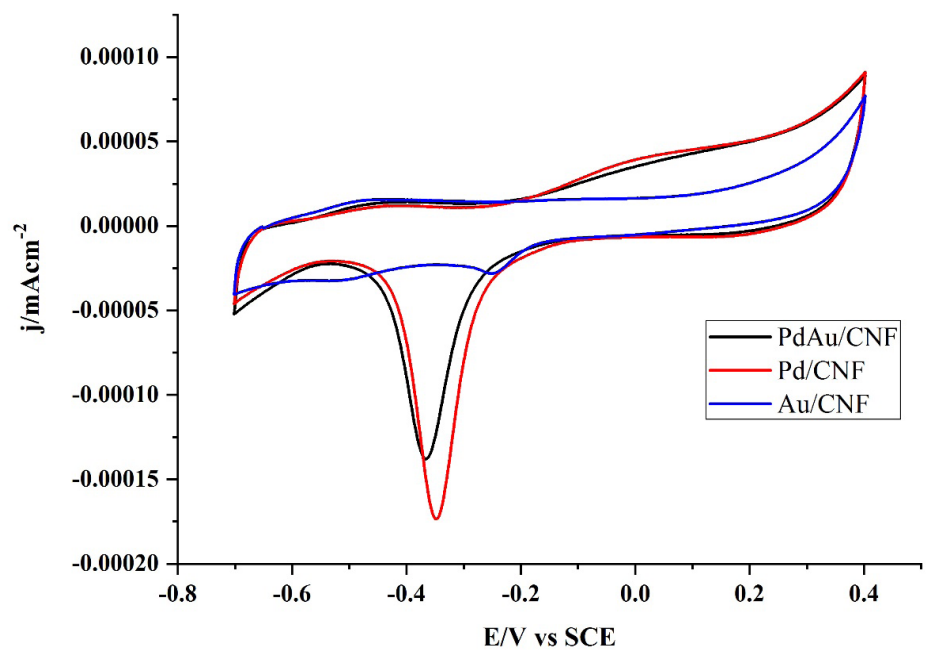

FIGURE 4. Cyclic voltammetry (CV) test in $50 \mathrm{mV} / \mathrm{s}$ in $1 \mathrm{M} \mathrm{KOH}$ for different catalyst samples

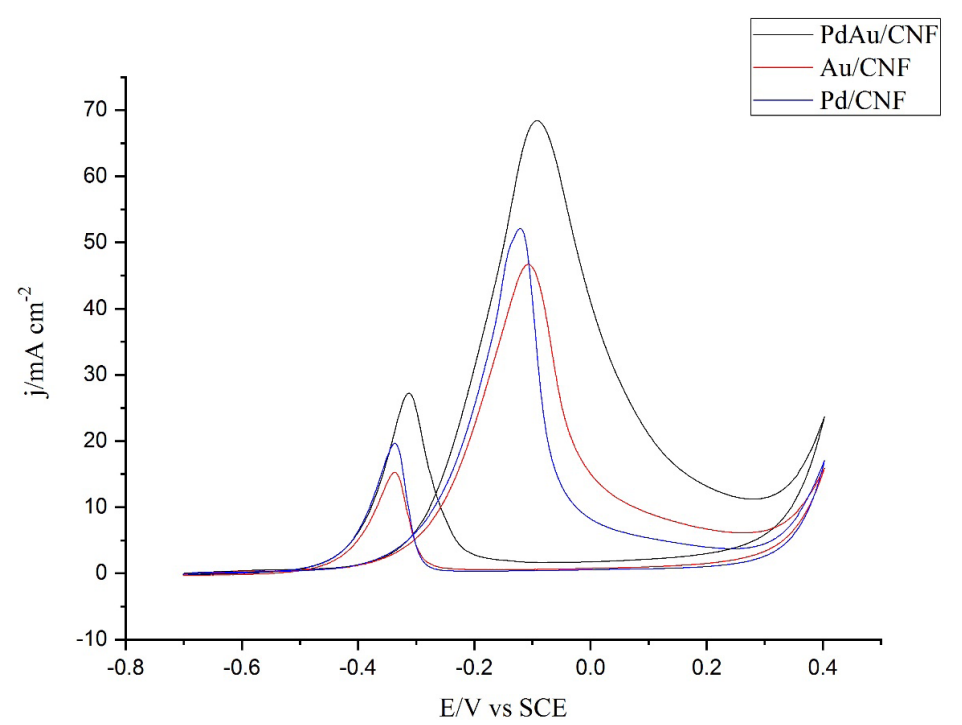

FIGURE 5. Cyclic voltammetry (CV) test in $50 \mathrm{mV} / \mathrm{s}$ in $0.5 \mathrm{M}$ glycerol/1 $\mathrm{M} \mathrm{KOH}$ solution for different catalyst samples 


\section{ADSORPTION PROPERTIES AND DISSOCIATION OF THE GLYCEROL ON PDAU ALLOY SURFACE}

$\mathrm{PdAu}$ alloy catalyst is further studied from the theoretical surface reaction point using density functional theory (DFT). Using this technique, glycerol dissociation during the oxidation reaction of glycerol can be studied. The adsorption energy on the dehydrogenation of glycerol is calculated as:

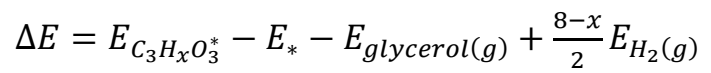

Tables 1 and 2 show the properties of adsorption species that occur on the catalyst surfaces of $\mathrm{PdAu}$ and $\mathrm{Au}$, respectively. Au catalyst surface model was used as a comparison with PdAu in this study. The reaction mechanism of the glycerol dissociation is from (2) to (8).

$$
\begin{gathered}
\mathrm{C}_{3} \mathrm{H}_{8} \mathrm{O}_{3} \rightarrow * \mathrm{C}_{3} \mathrm{H}_{8} \mathrm{O}_{3} \\
* \mathrm{C}_{3} \mathrm{H}_{8} \mathrm{O}_{3} \rightarrow * \mathrm{C}_{3} \mathrm{H}_{7} \mathrm{O}_{3}+\mathrm{H}^{+} \\
* \mathrm{C}_{3} \mathrm{H}_{7} \mathrm{O}_{3}+\mathrm{H}^{+} \rightarrow * \mathrm{C}_{3} \mathrm{H}_{6} \mathrm{O}_{3}+2 \mathrm{H}^{+} \\
* \mathrm{C}_{3} \mathrm{H}_{6} \mathrm{O}_{3}+2 \mathrm{H}^{+} \rightarrow * \mathrm{C}_{3} \mathrm{H}_{5} \mathrm{O}_{3}+3 \mathrm{H}^{+} \\
* \mathrm{C}_{3} \mathrm{H}_{5} \mathrm{O}_{3}+3 \mathrm{H}^{+} \rightarrow * \mathrm{C}_{3} \mathrm{H}_{4} \mathrm{O}_{3}+4 H^{+} \\
* \mathrm{C}_{3} \mathrm{H}_{4} \mathrm{O}_{3}+4 \mathrm{H}^{+} \rightarrow * \mathrm{C}_{3} \mathrm{H}_{3} \mathrm{O}_{3}+5 \mathrm{H}^{+} \\
* \mathrm{C}_{3} \mathrm{H}_{3} \mathrm{O}_{3}+5 \mathrm{H}^{+} \rightarrow * \mathrm{C}_{3} \mathrm{H}_{2} \mathrm{O}_{3}+6 \mathrm{H}^{+}
\end{gathered}
$$

\begin{tabular}{|c|c|c|c|c|c|}
\hline Adsorbate & $\begin{array}{c}\text { Adsorption energy, } \\
\text { Eads }(\mathrm{eV})\end{array}$ & $\begin{array}{c}\text { Bond length } \\
\text { Au-O }(\AA)\end{array}$ & $\begin{array}{c}\text { Bond length Pd } \\
\quad-\mathrm{O}(\AA)\end{array}$ & $\begin{array}{c}\text { Bond length } A u \\
-C(\AA)\end{array}$ & $\begin{array}{l}\text { Bond length } \\
\mathrm{Pd}-\mathrm{C}(\AA)\end{array}$ \\
\hline $\mathrm{CH}_{2} \mathrm{OHCHOHCH}_{2} \mathrm{OH}$ & -0.34 & 2.87 & - & - & - \\
\hline $\mathrm{CHOH}_{2} \mathrm{COHCH}_{2} \mathrm{OH}$ & 0.46 & - & 3.56 & 3.81 & - \\
\hline $\mathrm{CH}_{2} \mathrm{OHCOCH}_{2} \mathrm{OH}$ & 0.47 & - & 3.80 & - & - \\
\hline $\mathrm{CHOHCOCH}_{2} \mathrm{OH}$ & 1.32 & - & 3.35 & - & 4.03 \\
\hline $\mathrm{CHOHCOCHOH}$ & 1.70 & - & - & 3.73 & 3.15 \\
\hline $\mathrm{CHOHCOCHO}$ & 2.00 & - & $\begin{array}{l}2.14 \\
2.23\end{array}$ & - & \\
\hline СHOCOCHO & 2.96 & 3.11 & $\begin{array}{l}2.09 \\
2.27\end{array}$ & - & - \\
\hline $\mathrm{CHOCO}$ & -13.87 & - & - & - & 2.00 \\
\hline $\mathrm{CO}$ & 0.61 & - & - & - & 1.91 \\
\hline
\end{tabular}

TABLE 1. Adsorption properties of the species adsorbate on the PdAu catalyst surface

TABLE 2. Adsorption properties of the species adsorbate on the Au catalyst surface

\begin{tabular}{lccc}
\hline \multicolumn{1}{c}{ Adsorbate } & $\begin{array}{c}\text { Adsorption energy, } \\
\text { Eads }(\mathrm{eV})\end{array}$ & $\begin{array}{c}\text { Bond length } \\
\mathrm{Au}-\mathrm{O}(\AA)\end{array}$ & $\begin{array}{c}\text { Bond length } \\
\mathrm{Au}-\mathrm{C}(\AA)\end{array}$ \\
\hline $\mathrm{CH}_{2} \mathrm{OHCHOHCH}{ }_{2} \mathrm{OH}$ & -0.76 & 2.85 & - \\
$\mathrm{CHOH}_{2} \mathrm{COHCH}_{2} \mathrm{OH}$ & -0.01 & 3.25 & 3.67 \\
$\mathrm{CH}_{2} \mathrm{OHCOCH}_{2} \mathrm{OH}$ & -0.03 & 3.47 & - \\
$\mathrm{CHOHCOCH}_{2} \mathrm{OH}$ & 1.05 & 3.74 & 3.93 \\
$\mathrm{CHOHCOCHOH}$ & 1.22 & 4.07 & 3.26 \\
$\mathrm{CHOHCOCHO}$ & & & 3.72 \\
& 1.97 & 2.30 & - \\
$\mathrm{CHOCOCHO}$ & & 2.47 & - \\
$\mathrm{CHOCO}$ & 2.96 & 2.81 & 2.36 \\
$\mathrm{CO}$ & -13.92 & 2.96 & 2.05 \\
\hline
\end{tabular}


The mechanism of the dehydrogenation to produce proton in the electrochemical reaction started as the glycerol is adsorbed on the PdAu surface, as shown in Figure 6(a) and (2). All the adsorption positions in this paper have been optimized. In Figure 6(a), the glycerol is adsorbed on the Au atom in PdAu through oxygen atom in glycerol. This adsorption generates the adsorption energy of $-0.34 \mathrm{eV}$, as shown in Table 1 . The bond length of the $\mathrm{Au}$ atom and oxygen atom after the adsorption occurs is $2.87 \AA$.
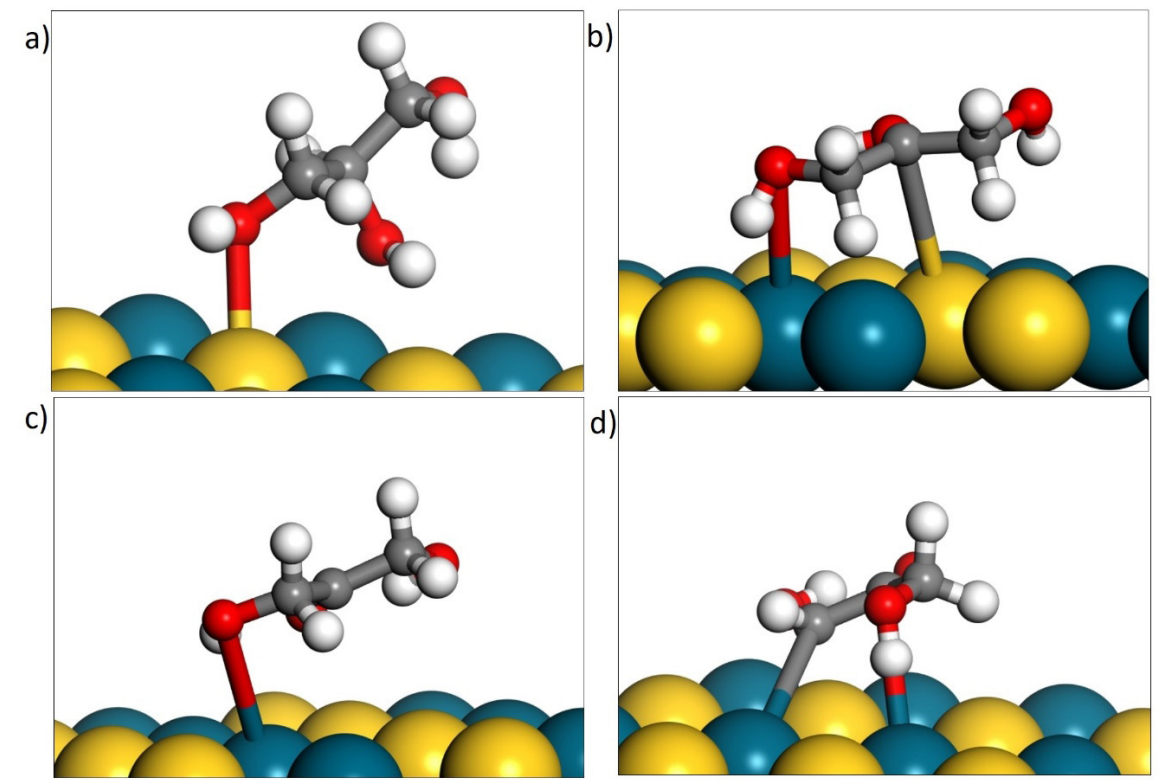

FIGURE 6. Adsorption species on PdAu catalyst surface (a) glycerol or $\mathrm{CH}_{2} \mathrm{OHCHOHCH}_{2} \mathrm{OH}$, (b) $\mathrm{CHOH}_{2} \mathrm{COHCH}_{2} \mathrm{OH}$, (c) $\mathrm{CH}_{2} \mathrm{OHCOCH}_{2} \mathrm{OH}$ and (d) $\mathrm{CHOHCOCH}_{2} \mathrm{OH}$

Next for dehydrogenation reaction or next hydrogen dissociation from the glycerol occur as in reaction (3) which produces adsorbate $* \mathrm{C}_{3} \mathrm{H}_{7} \mathrm{O}_{3}$ and a proton. Figure 6(b) shows how this adsorbate is adsorbed on the surface of $\mathrm{PdAu}$, i.e., through oxygen atom is adsorbed on $\mathrm{Pd}$ atom (Pd-O), and the carbon atom in $* \mathrm{C}_{3} \mathrm{H}_{7} \mathrm{O}_{3}$ is adsorbed on $\mathrm{Au}$ atom $(\mathrm{Au}-\mathrm{C})$ in $\mathrm{PdAu}$. Both bond lengths of $\mathrm{Pd}-\mathrm{O}$ and Au-O are $3.56 \AA$ and $3.81 \AA$, respectively. This adsorption has produced an adsorption energy of $0.46 \mathrm{eV}$.
The next hydrogen dissociation from the glycerol to produce adsorbate of $* \mathrm{C}_{3} \mathrm{H}_{6} \mathrm{O}_{3}$ as (4) has adsorbed on the surface of PdAu through Pd atoms. Through this, adsorption has produced an adsorption energy of $0.47 \mathrm{eV}$. The bond length of Pd-O elongated to $3.80 \AA$ A compared to adsorption through (3). Subsequent adsorption produces an adsorbate of $* \mathrm{C}_{3} \mathrm{H}_{5} \mathrm{O}_{3}$ in (5) as shown in Figure 6(d). This adsorption requires two active sites $\mathrm{Pd}$ atoms have produced adsorption energy of $1.32 \mathrm{eV}$. Both Pd-O and Pd-C have produced bond lengths of $3.35 \AA$ and $4.03 \AA$, respectively.

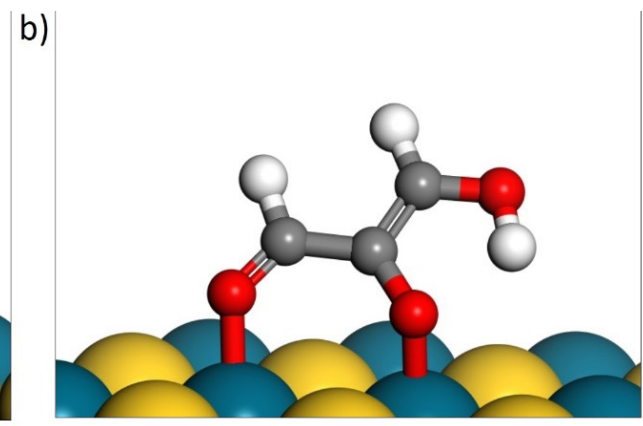

FIGURE 7. Adsorption species on PdAu catalyst surface (a) $\mathrm{CHOHCOCHOH}$ and (b) $\mathrm{CHOHCOCHO}$ 
Each mechanism step in glycerol oxidation requires a different active site. Such as the next dissociation in (6) which produces adsorbate of $* \mathrm{C}_{3} \mathrm{H}_{4} \mathrm{O}_{3}$ requires $\mathrm{Pd}$ and $\mathrm{Au}$ active site for both carbons in ${ }^{*} \mathrm{C}_{3} \mathrm{H}_{4} \mathrm{O}_{3}$ to be adsorbed. Figure 7(a) shows which carbon atoms in the adsorbate of $* \mathrm{C}_{3} \mathrm{H}_{4} \mathrm{O}_{3}$ have adsorbed on the surface of $\mathrm{PdAu}$ with adsorption energy of $1.70 \mathrm{eV}$. This adsorption has resulted in a bond length of Pd-C and Au-C of 3.15 and $3.73 \AA$, respectively. Further dissociation in (7) has produced by position adsorbate atoms on both $\mathrm{Pd}$ atoms, as shown in Figure 7(b). Both bonding at these Pd atoms is $2.09 \AA$ and $2.23 \AA$ with an adsorption energy of $2.00 \mathrm{eV}$. Further dissociation on the surface of $\mathrm{PdAu}$ has produced $* \mathrm{C}_{3} \mathrm{H}_{2} \mathrm{O}_{3}$ adsorbate, as shown in (8) and Figure 8(a). In Figure 8(a), three atom oxygens in ${ }^{*} \mathrm{C}_{3} \mathrm{H}_{2} \mathrm{O}_{3}$ adsorbed on two $\mathrm{Pd}$ atoms and an Au atom. These three bonding (two Pd-O and one Au-O) have value, as shown in Table 1 is 2.09, 2.27, and $3.11 \AA$, respectively.

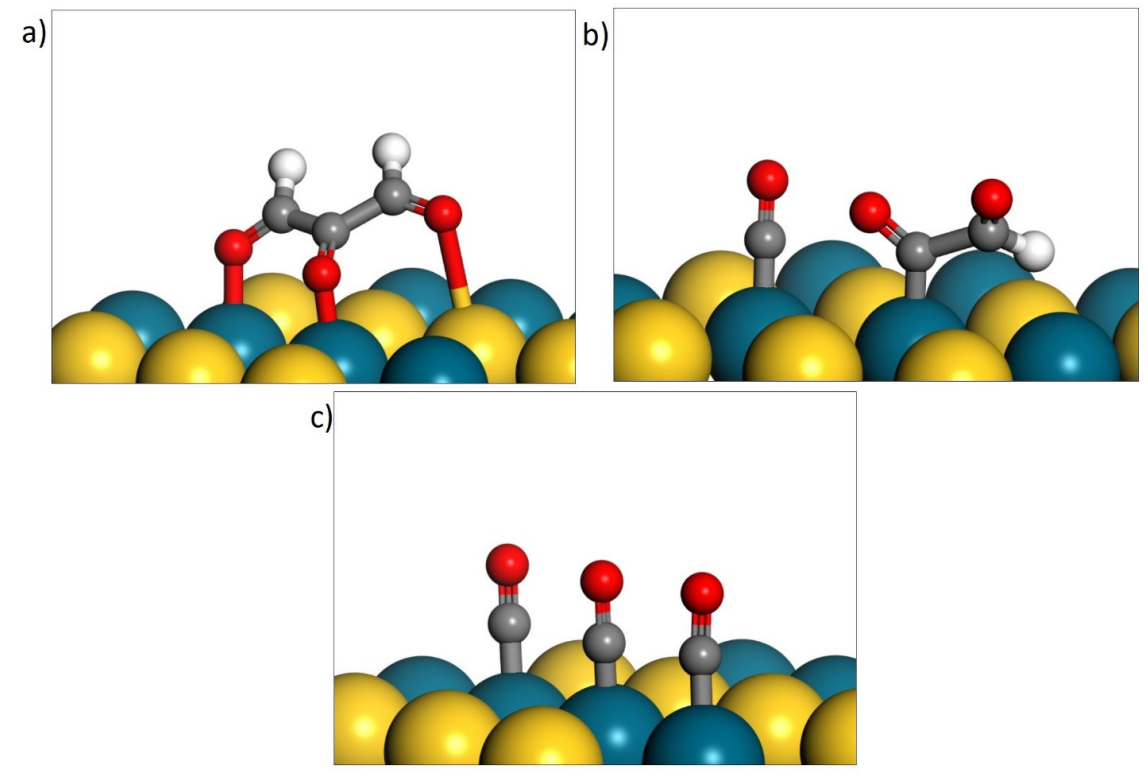

FIGURE 8. Adsorption species on PdAu catalyst surface (a)

$\mathrm{CHOCOCHO}$, (b) CHOCO and $\mathrm{CO}$ and (c) three molecules of $\mathrm{CO}$

The adsorbate $* \mathrm{C}_{3} \mathrm{H}_{2} \mathrm{O}_{3}$ is breaking to form $* \mathrm{COCOH}$ and ${ }^{*} \mathrm{CO}$ adsorbate on PdAu, as shown in (9) and Figure 8(b). The optimized model shows that this adsorbate is more stable in adsorption on Pd atoms than Au atoms. Adsorption energy generated through this adsorption for (9) is $-13.87 \mathrm{eV}$. The bond length $\mathrm{Pd}-\mathrm{C}$ in ${ }^{*} \mathrm{COCOH}$ has been produced with a value of $2.27 \AA$. While $\mathrm{Pd}-\mathrm{C}$ in ${ }^{*} \mathrm{CO}$ has produced a bong length of $2.09 \AA$. The ${ }^{*} \mathrm{COCOH}$ adsorbate then dissociates to form three ${ }^{*} \mathrm{CO}$ molecules on the surface of PdAu, as shown in (10) and Figure 8(b). A weak adsorption energy value of $0.61 \mathrm{eV}$ has been produced with a bond length of $\mathrm{Pd}-\mathrm{C}$ is $1.91 \AA$.

From the experiment section in $\mathrm{CV}$ analysis, $\mathrm{Au} / \mathrm{CNF}$ showed a slightly better oxidation peak, which is a little more negative than PdAu. If we look at the comparison from a theoretical point of view, namely the dissociation of glycerol PdAu and Au, as shown in Tables 1 and 2, the Au model also shows a slightly better dissociation than
PdAu. Both theoretical and experimental results support each other. However, $\mathrm{PdAu} / \mathrm{CNF}$ has a higher current density than $\mathrm{Pd} / \mathrm{CNF}$ and $\mathrm{Au} / \mathrm{CNF}$ because it is supported by CNF. In addition, the theoretical result has showed something where experimental cannot be tested, namely the final step of $\mathrm{CO}$ adsorption.

The adsorption of $\mathrm{CO}$ is an important step in the oxidation of glycerol. The adsorption of $\mathrm{CO}$ on the surface of the catalyst should not be too high as it can produce catalyst poisoning. If poisoning happens, the active site for the adsorption of other molecules cannot be carried out. But if adsorption is weak, the oxidation process will not be completed. The adsorption energy of CO indicates that the use of the Au catalyst model has resulted in weak adsorption. The value is $1.01 \mathrm{eV}$ is weak compared to $\mathrm{PdAu}$, which produces $0.61 \mathrm{eV}$ in adsorption of $\mathrm{CO}$. This also means that long-term endurance or durability tests using $\mathrm{Au}$ will be lower compared to PdAu. 


\section{CONCLUSION}

The catalyst of PdAu has been synthesized for oxidation reaction in Direct Glycerol Fuel Cell. The PdAu is supported on the CNF surface. The FESEM and TEM image has shown the nanoparticle of PdAu supported on $\mathrm{CNF}$. The particle size of PdAu synthesized in this paper is $4 \mathrm{~nm}$ to $6 \mathrm{~nm}$, while the CNF has a diameter size of 80 $\mathrm{nm}$ to $130 \mathrm{~nm}$. XRD analysis has shown that PdAu is successfully allocated when peaks are shifted compared to $\mathrm{Pd} / \mathrm{CNF}$ and $\mathrm{Au} / \mathrm{CNF}$. In $\mathrm{CV}$ analysis, $\mathrm{PdAu} / \mathrm{CNF}$ has produced an oxidation peak and current density at $-0.9 \mathrm{~V}$ vs. SCE and $70 \mathrm{~mA} / \mathrm{cm}^{2}$, respectively. From a theoretical point of view, the PdAu catalyst model has been tested for glycerol and adsorbate adsorption, where the $\mathrm{Au}$ catalyst model is used as a reference. Each mechanism of glycerol dissociation step during glycerol oxidation, different atomic active sites are required in $\mathrm{PdAu}$. For example, for glycerol adsorption, Au atom as an active site while for $* \mathrm{C}_{3} \mathrm{H}_{7} \mathrm{O}_{3}$ requires $\mathrm{Pd}$ atom and $\mathrm{Au}$ atom as an active site. The Au catalyst model shows better adsorption as $\mathrm{Au} / \mathrm{CNF}$ has a slightly more negative oxidation peak than PdAu. Nevertheless, the Au catalyst showed less durability compared to PdAu.

\section{ACKNOWLEDGEMENTS}

The authors gratefully acknowledge the financial support for this work by Universiti Kebangsaan Malaysia under grant GGPM-2018-054 and Dana Pecutan Penerbitan Tahun 2020 (PP-SELFUEL-2020).

\section{REFERENCES}

Abdullah, N., Kamarudin, S.K., Shyuan, L.K. \& Karim, N.A. 2017. Fabrication and characterization of new composite $\mathrm{Ti}_{\mathrm{O} 2}$ carbon nanofiber anodic catalyst support for direct methanol fuel cell via electrospinning method. Nanoscale Research Letters 12(1): 613.

Alias, M.S., Kamarudin, S.K., Zainoodin, A.M. \& Masdar, M.S. 2020. Active direct methanol fuel cell: An overview. International Journal of Hydrogen Energy 45(38): 19620 19641.

Araujo, H.R., Zanata, C.R., Teixeira-Neto, E., de Lima, R.B., Batista, B.C., Giz, M.J. \& Camara, G.A. 2019. How the adsorption of Sn on Pt (100) preferentially oriented nanoparticles affects the pathways of glycerol electrooxidation. Electrochimica Acta 297: 61-69.

Brueckner, T.M., Wheeler, E., Chen, B., El Sawy, E.N. \& Pickup, P.G. 2019. Screening of catalysts for the electrochemical oxidation of organic fuels in a multi-anode proton exchange membrane cell. Journal of The Electrochemical Society 166(13): F942-F948.

Cui, X., Li, Y., Zhao, M., Xu, Y., Chen, L., Yang, S. \& Wang, Y. 2019. Facile growth of ultra-small Pd nanoparticles on zeolite-templated mesocellular graphene foam for enhanced alcohol electro-oxidation. Nano Research 12(2): 351-356.
Day, C. \& Day, G. 2017. Climate change, fossil fuel prices and depletion: The rationale for a falling export tax. Economic Modelling 63: 153-160.

Gao, F., Zhang, Y., Song, P., Wang, J., Yan, B., Sun, Q., Li, L., Zhu, X. \& Du, Y. 2019. Shape-control of one-dimensional PtNi nanostructures as efficient electrocatalysts for alcohol electro-oxidation. Nanoscale 11(11): 4831-4836.

Ghosh, S., Bysakh, S. \& Basu, R.N. 2019. Bimetallic Pd96Fe4 nanodendrites embedded in graphitic carbon nanosheets as highly efficient anode electrocatalysts. Nanoscale Advances 1(10): 3929-3940.

Houache, M.S., Hughes, K., Ahmed, A., Safari, R., Liu, H., Botton, G.A. \& Baranova, E.A. 2019. Electrochemical valorization of glycerol on Ni-rich bimetallic NiPd nanoparticles: Insight into product selectivity using in situ polarization modulation infrared-reflection absorption spectroscopy. ACS Sustainable Chemistry \& Engineering 7(17): 14425-14434.

Karim, N.A. \& Kamarudin, S.K. 2017. Novel heat-treated cobalt phthalocyanine/carbon-tungsten oxide nanowires $(\mathrm{CoPc} / \mathrm{C}$ W18O49) cathode catalyst for direct methanol fuel cell. Journal of Electroanalytical Chemistry 803: 19-29.

Karim, N.A., Kamarudin, S.K. \& Loh, K.S. 2017. Performance of a novel non-platinum cathode catalyst for direct methanol fuel cells. Energy Conversion and Management 145: 293307.

Martins, C.A., Ibrahim, O.A., Pei, P. \& Kjeang, E. 2019. In situ decoration of metallic catalysts in flow-through electrodes: Application of $\mathrm{Fe} / \mathrm{Pt} / \mathrm{C}$ for glycerol oxidation in a microfluidic fuel cell. Electrochimica Acta 305: 47-55.

Mori, D. \& Hirose, K. 2009. Recent challenges of hydrogen storage technologies for fuel cell vehicles. International Journal of Hydrogen Energy 34(10): 4569-4574.

Nascimento, A.P. \& Linares, J.J. 2014. Performance of a direct glycerol fuel cell using $\mathrm{KOH}$ doped polybenzimidazole as electrolyte. Journal of the Brazilian Chemical Society 25(3): 509-516.

Ning, X., Zhou, X., Luo, J., Ma, L., Xu, X. \& Zhan, L. 2019. Glycerol and formic acid electro-oxidation over Pt on S-doped carbon nanotubes: Effect of carbon support and synthesis method on the metal-support interaction. Electrochimica Acta 319: 129-137.

Sun, Q., Gao, F., Zhang, Y., Wang, C., Zhu, X. \& Du, Y. 2019. Ultrathin one-dimensional platinum-cobalt nanowires as efficient catalysts for the glycerol oxidation reaction. Journal of Colloid and Interface Science 556: 441-448.

Tam, B., Duca, M., Wang, A., Fan, M., Garbarino, S. \& Guay, D. 2019. Promotion of glycerol oxidation by selective $\mathrm{Ru}$ decoration of (100) domains at nanostructured Pt electrodes. ChemElectroChem 6(6): 1784-1793.

Wang, C., Song, P., Gao, F., Song, T., Zhang, Y., Chen, C., Li, L., Jin, L. \& Du, Y. 2019. Precise synthesis of monodisperse PdAg nanoparticles for size-dependent electrocatalytic oxidation reactions. Journal of Colloid and Interface Science 544: 284-292.

Wang, J., Wang, H. \& Fan, Y. 2018. Techno-economic challenges of fuel cell commercialization. Engineering 4(3): 352-360.

Wang, W., Wang, Z., Wang, J., Zhong, C.J. \& Liu, C.J. 2017. Highly active and stable Pt-Pd alloy catalysts synthesized by 
room-temperature electron reduction for oxygen reduction reaction. Advanced Science 4(4): 1600486.

Yahya, N., Kamarudin, S.K., Karim, N.A., Masdar, M.S. \& Loh, K.S. 2017. Enhanced performance of a novel anodic PdAu/ VGCNF catalyst for electro-oxidation in a glycerol fuel cell. Nanoscale Research Letters 12 (1): 605.

Zakaria, K., McKay, M., Thimmappa, R., Hasan, M., Mamlouk, M. \& Scott, K. 2019. Direct glycerol fuel cells: Comparison with direct methanol and ethanol fuel cells. ChemElectroChem 6(9): 2578-2585.

Zhang, Y., Gao, F., Song, P., Wang, J., Song, T., Wang, C., Chen, C., Jin, L., Li, L., Zhu, X. \& Du, Y. 2019. Superior liquid fuel oxidation electrocatalysis enabled by novel bimetallic PtNi nanorods. Journal of Power Sources 425: 179-185.

Zhang, Z.C., Lerner, B., Lei, G.D. \& Sachtler, W.M.H. 1993. Hydrocarbon-induced agglomeration of Pd particles in $\mathrm{Pd} /$ HZSM-5. Journal of Catalysis 140(2): 481-496.

Zhou, Y., Shen, Y., Xi, J. \& Luo, X. 2019. Selective electrooxidation of glycerol to dihydroxyacetone by PtAg skeletons. ACS Applied Materials \& Interfaces 11(32): 28953-28959.
Nabila A. Karim*, Muhammad Syafiq \& Siti Kartom Kamarudin Fuel Cell Institute

Universiti Kebangsaan Malaysia

43600 UKM Bangi, Selangor Darul Ehsan

Malaysia

Norilhamiah Yahya

Malaysian Institute of Chemical and Bioengineering Technology Universiti Kuala Lumpur

78000 Alor Gajah, Melaka

Malaysia

*Corresponding author; email: nabila.akarim@ukm.edu.my

Received: 11 August 2020

Accepted: 11 September 2020 